
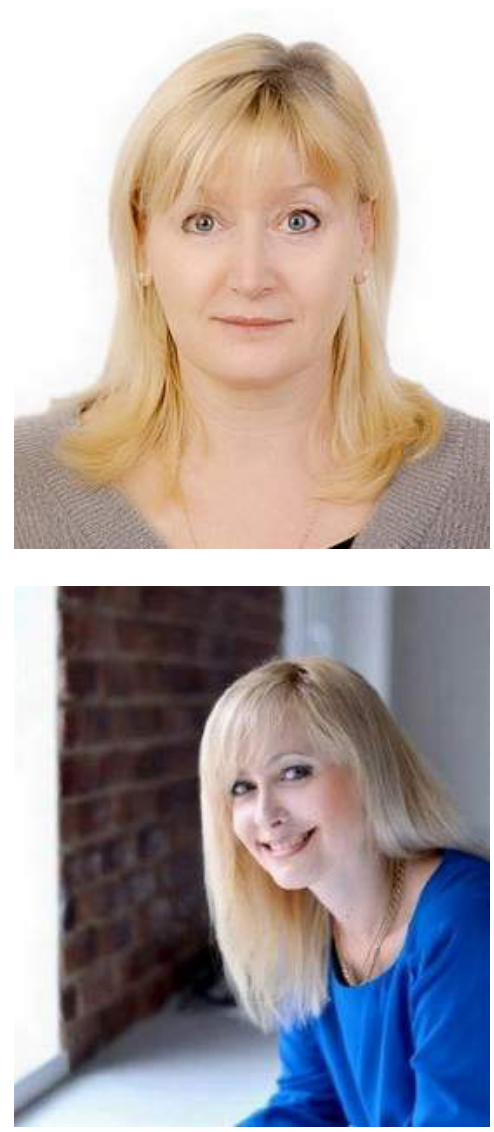

Наталія Борисенко,

кандидат педагогічних наук, доцент кафедри природничо-математичних дисциплін та логопедії, Херсонський державний університет (м. Херсон, Україна)

\section{Nataliya Borysenko,}

PhD in Education, Associate Professor, Department of Natural and Mathematical Disciplines and Speech Therapy, Kherson State University (Kherson, Ukraine) nataborisenchik15@gmail.com ORCID ID 0000-0003-3515-4766

\section{Вероніка Денисенко,}

кандидат педагогічних наук, доцент кафедри педагогіки дошкільної та початкової освіти, Херсонський державний університет (м.Херсон, Україна)

\author{
Veronika Denysenko, \\ $\mathrm{PhD}$ in Education, Associate Professor, Department \\ of Pedagogy of Preschool and Primary Education, \\ Kherson State University \\ (Kherson, Ukraine) \\ veronikaden@ukr.net
}

Удк 343

\title{
ПЕДАГОГІЧНІ УМОВИ ФОРМУВАННЯ ОСНОВ ПРАВОВИХ ЗНАНЬ УЧНІВ ПОЧАТКОВОЇ ШКОЛИ
}

Анотація. Процес реалізації компетентісного підходу в початковій освіті виявив необхідність окреслення сучасних основ правових знань учнів початкової школи на засадах демократії. В Концепції Нової української школи зазначено, що освітній процес має бути організовано за моделлю поваги до прав людини, демократії, підтримки добрих ідей. Формувати таку модель та закладати основні стереотипи демократичної поведінки особистості можливо тільки на засадах цінностей демократичного суспільства - верховенства прав людини, рівності і взаємній відповідальності.

Враховуючи особистості дітей молодшого шкільного віку слід виходити з певних принципів їх правового виховання. Сама специфіка правового виховання вимагає тісного поєднання його з практичною діяльністю школярів. Адже знання права нерозривно пов'язані з повсякденною діяльністю і поведінкою учнів.

Сама специфіка правового виховання вимагає тісного поєднання його з практичною діяльністю школярів. Адже правова освіта для демократичного громадянства не є простим поглинанням фактичних знань, а є практичним розумінням, набуттям навичок та здібностей, ціннісних орієнтацій та позицій. Основним $€$ те, що учні мають навчатись демократичному громадянству та засвоїти знання про права та обов'язки на прикладах, якими здійснюється та організовується учнівське життя через формальні та інформальні методи навчання.

Ключові слова: демократичний менеджмент, педагогічні умови, правове виховання, правові знання, принципи, форми та методи, молодші школярі.

\section{PEDAGOGICAL CONDITIONS IN DEVELOPING THE FOUNDATIONS OF LEGAL KNOWLEDGE OF PRIMARY SCHOOL STUDENTS}

Abstract. The process of implementing the competent approach in primary education revealed the need to outline the modern ways of national education for the younger generation of children and young people. It is marked in Conception of New Ukrainian school, that an educational process must be organized after the model of respect to the human, democracy, support of kind ideas rights. The purpose of the paper is to substantiate the pedagogical conditions for the formation of legal knowledge of elementary school students. 
Taking into account the personality of children of elementary school age should proceed from certain principles of their legal education. The very specifics of legal education require a close combination of it with the practical activities of schoolchildren. After all, knowledge of law is inextricably linked with the daily activities and behavior of students.

To form such model and mortgage the basic stereotypes of democratic behavior of personality maybe only on principles of values of democratic society are supremacies of human, equality rights and to mutual responsibility.

The specific of legal education requires close combination him with practical activity of schoolchildren. In fact legal education for democratic citizenship is not simple absorption of actual knowledge, but is the practical understanding, acquisition of skills and capabilities, valued orientations and positions. Basic is that students must study to democratic citizenship and master knowledge about rights and duties on examples, that student's life comes true and gets organized through formal and informal methods of studies.

Keywords: Democratic management, pedagogical conditions, legal education, legal knowledge, principles, forms and methods, junior schoolchildren.

\section{ВСТУП}

Постановка проблеми. Перебуваючи у процесі стрімких соціально-економічних змін, Україна надзвичайно гостро відчуває потребу підготовки і виховання нової генерації громадян на засадах цінностей демократичного суспільства - верховенстві прав людини, рівності і взаємній відповідальності. Від гірських шкіл Карпат до сільських шкіл степової Наддніпрянщини має працювати успішна освітня модель формування громадянських якостей здобувача освіти, незалежно від його національності, мови спілкування, конфесійної приналежності, політичних переконань, походження, майнового стану та специфічних особливостей регіону. Виховання справжнього громадянина можливе лише за умови створення демократичного середовища у навчальному закладі, де учень на власному досвіді навчається брати відповідальність та приймати рішення, розуміє та реагує на процеси, що відбуваються в його оточенні через призму демократичних процесів у суспільстві.

Аналіз останніх досліджень і публікацій. На різних етапах розвитку наукової педагогічної думки проблема формування правових знань перебувала у полі зору багатьох науковців (М.Фіцули, І.Беха, Н. Бібік, І.Запорожана, Н.Кусайкіної, І.Іванюка, А.Токаревої) нові підходи до трактування основних понять знаходимо у Л. Паращенко, Ю. Молчанової; Н. Протасової, С.Ратушняка та інших.

Вчені одностайні у думці, що сучасна освіта має спрямовуватися на формування особистісних компетентностей дитини, сприяти максимальній інтеграції в соціум та адаптації до сучасних вимог життя. Учні повинні мати чітке розуміння того, що таке демократія, і якими правами людини вони користуються, якими документами дані права були закріплені, і яким чином учні можуть бути захищені або змушені діяти. Як майбутні громадяни, вони мають знати принципи дії конституції своєї країни як політичної системи, щоб стати повноправними і активними членами суспільства, учні повинні мати можливість працювати разом в інтересах загального блага, навчитися поважати думку, навіть протилежну, кожного, а також культивувати звички і цінності демократії і прав людини в повсякденному житті й діяльності. Представлене розуміння в цілому, співпадає з баченням цього поняття науковцями держав - членів Євросоюзу (Р. Голлоб, П. Крапф, О. Олафсдоттір, В. Вайдінгер).

\section{МЕТА І ЗАВДАННЯ ДОСЛІДЖЕННЯ.}

Метою статті $€$ обґрунтування принципів та педагогічних умов ефективного формування правової культури учнів школи I ступеня, що передбачають застосування конструктивних методів навчання та орієнтовані на демократичну модель суспільства.

\section{РЕЗУЛЬТАТИ ДОСЛІДЖЕННЯ}

Основу правової свідомості особи становлять правові уявлення та ставлення до них - переконання. Зміст правових уявлень і понять визначається правом, загальнолюдською мораллю та національною приналежністю людини, особливостями суспільних відносин, життєвою практикою. На думку М. Хартлея і Т. Хадлестон "демократичні цінності й практики мають бути вивчені й закріплені для використання в рішенні існуючих проблем кожного наступного покоління. Щоб стати повноправними і активними членами суспільства, громадяни повинні мати можливість працювати разом в інтересах загального блага, поважати думку, навіть протилежну, кожного, брати участь у політичному процесі, а також культивувати звички і цінності демократії і прав людини в повсякденному житті й діяльності». [5, с.8].

Провідні начала - принципи права, які проходять через всю систему правового виховання, сприяють, формуванню пізнавально-ціннісного ставлення учнів до знань, ціннісних орієнтацій особи, які регулюють ії поведінку. Такими ідеями є, зокрема, принципи: законності, справедливості, рівноправності, єдності прав і обов'язків, відповідальності. Бекман і Трафффорд застосовують три критерії для оцінювання процесу формування правосвідомості, що базуються на трьох основних принципах ОДГ, визначених Радою Європи: - права і відповідальність; - активна участь; - визнання і повага різноманітності [2, с.18].

Зважаючи на те, що «право» $є$ основним принципом побудови демократичного, громадянського й відкритого суспільства, учень має знати що таке «права людини». За словником, «права людини» - це єдині норми для всіх людей без будь-яких дискримінацій, яких вони мають дотримуватись впродовж життя, та умови для задоволення яких має забезпечувати держава

У процесі формування правової культури здійснюється усвідомлення людиною себе як особистості і свого місця в правовій суспільній діяльності людей. На цьому етапі в дитини виховується схильність до самоконтролю, вона може постійно спрямовувати і контролювати власні вчинки і поведінку В учнів потрібно сформувати уявлення: якщо право закріплює основи справедливості, то законність є одним із основних засобів, який забезпечує справедливість. Ось чому для виховання особистості винятково важлива ідея справедливості, яка с основною ідеєю права. 
Методично виправданий розгляд принципу рівноправності у тісному зв'язку з історичними етапами розвитку суспільства, починаючи з виникнення держави. Принцип рівноправності $є$ вихідним. 3 нього випливає ідея про рівність не тільки прав, а й обов'язків, їх єдності, бо не може бути прав без обов'язків. Для усвідомлення ідеї єдності прав і обов'язків як стрижневої, провідної, важливо правильно розуміти співвідношення її структурних, складових елементів - понять і часткових ідей. У цьому зв'язку визначаємо основне коло понять, часткових ідей, на базі яких повинна будуватися робота над фрормуванням правового принципу невіддільності здійснення прав і свобод від виконання громадянами своїх обов'язків. Зокрема, під час формування цього принципу рекомендується звернутися до наступних правових понять, положень, які по суті становлять зміст основних прав і обов'язків громадян, класифікувавши їх на три групи за сфрерою реалізації в суспільному житті [3, с.50-51]:

1. Особисті права і обов'язки, які необхідні для існування і вільного розвитку особи.

2. Соціально-економічні та культурні права і обов'язки, які пов'язані із реалізацією особи в сфері соціальноекономічних відносин, духовних цінностей суспільства.

3. Політичні права і обов'язки, які пов'язані з участю громадян в політичному житті суспільства.

Засвоенню змісту цих понять стає можливим завдяки впровадженню Освіти для демократичного громадянства і Освіти з прав людини (ОДГ/ОПЛ) в освітній процесс початкової школи [1, 3]. Згідно вимог швейцарськоукраїнського проекту «DOCCU» (www.doccu.in.ua), який почав реалізуватися в закладах освіти України з 2018 року, розпочато впровадження розроблених матеріалів, що презентують доробок зарубіжних науковців 3 проблеми правового виховання на демократичних засадах [1-3]. Особливістю посібників є універсальність та адаптивність до освітніх систем країн-членів Ради Європи, гнучка структура, зручний і зрозумілий методичний інструментарій.

Правове виховання молодших школярів передбачає формування знань дитини про свої права та обов'язки, відповідальність за їх невиконання. Воно зорієнтоване на виховання поважного відношення до законів України, іiі Конституції. Щодо статей Конвенції про права людини, на які можна посилатися під час формування громадянської компетентності учнів у процесі навчання: право бути почутим (Ст.12); право на свободу висловлювання (Ст.13); право на свободу думки, вибору релігії (Ст.14); право на доступ до необхідної інформації (Ст.17); право на охорону здоров'я та медичне обслуговування (Ст.24); право на оцінку лікування та догляду (Ст.25); право на освіту (Ст.28); право на дозвілля та відпочинок (Ст.30); право на захист від наркотичних засобів, а також право на чисте довкілля, чисту воду (Ст.33).

Освіта для демократичного громадянства і освіта з прав людини тісно взаємопов'язані і підтримують одна одну. Вони розрізняються тематикою і масштабами, але не цілями й практичними методиками. Освіта для демократичного громадянства фокусує основну увагу на демократичних правах та обов'язках, а також на активній участі у громадянській, політичній, соціальній, економічній, правовій і культурній сферах життя суспільства. Натомість освіта з прав людини пов'язана з ширшим спектром прав людини і основних свобод в усіх аспектах життя людей [2, с.58].

Зважаючи на те, що організація і здійснення процесу громадянського виховання пов'язані з застосуванням певних форм, методів і засобів навчально-пізнавальної діяльності учнів, важливим для вчителя є вибір зазначених складових технології громадянського виховання, здатних забезпечити досягнення цілей демократичного навчання. Результати досліджень зарубіжних науковців свідчать, що перш за все, вони мають забезпечувати навчання:

- через активну дію (шляхом створення нового продукту і т. п.);

- через мислення (шляхом аналізу та фрормування нових поглядів);

- через спостереження та аналіз і прогнозування;

- через різноманітні вербальні фрорми навчання (лекція, розповідь тощо);

- через інструктажі, надання допомоги та співпрацю;

- через обговорення і дебати;

- через створення письмових освітніх продуктів (повідомлення, учнівський щоденник тощо);

- шляхом застосування різних способів виконання діяльності;

- через аналіз подій у реальному житті та власного досвіду;

Необхідність забезпечення навчання, орієнтованого на потреби учня, є важливим завданням для вчителів.

Виконання цього завдання буде ефективним лише за умови застосування конструктивістського навчання.

- учні конструюють або створюють власну структуру понять.

- нова інформація пов'язується з тим, що учень уже знає або розуміє.

- діти приходять до школи із власним життєвим досвідом;

- стать, належність до класу або етнічної групи, вік, релігійні вірування фрормують унікальний світогляд кожного учня;

- ми володіємо різними видами інтелекту, які виходять далеко за межі традиційного розуміння досягнення успіхів у математиці або мовах;

- не існує абсолютних стандартів визначення особистої або політичної доцільності.

Навчання має базуватись як на вивченні актуальних проблем через розумінням історичних систем, критичне мислення і набуття навичок, так і передачу знань, спільну роботу і партнерство. Це вимагає змін в нашому сприйнятті навчального процесу, де центром $€$ вчитель, щодо навчання через практику, дослідження та обмін досвідом.

Практичне впровадження наведених вище теоретичних положень ми здійснювали у процесі виробничої практики студентів напряму підготовки «Початкова освіта» Херсонського державного університету в базових 
закладах освіти № 3, 6, 9, 16, 28, 56 міста Херсона, де відбувалося цілеспрямоване і систематичне фрормування правової культури та правових уявлень молодших школярів на демократичних засадах 3 урахуванням рекомендацій та виокремлених педагогічних умов:

1) впровадження активних форм знайомства з правами людини на уроках, тематичних класних годинах, соціальному житті;

2) підвищення рівня правової культури шляхом залучення дітей до участі в сюжетно-рольових іграх з правової тематики;

3) використання системи правових ситуацій розроблених на засадах демократії з використанням інформаційнокомунікативних педагогічних технологій.

Формувальним етапом експерименту було охоплено 156 учнів експериментальних класів, в яких проходили практику підготовлені до такої роботи студенти, а одержані результати порівнювалися із показниками сформованості правової культури учнів контрольних класів (де діяльність студентів була спрямована на інші напрямки виховання).

В освітньому процесі початкової школи $є$ потенціал для реалізації зазначеного змісту. При цьому використовували можливості освітнього процесу початкової школи, що закладено в таких навчальних предметах як «Я у світі», «Літературне читання», «Математика», «Основи здоров'я» та ін. Крім того, до роботи були задіяні вправи з методичних посібників розроблених фахівцями швейцарсько-українського проекту DOCCU [1,2,3].

] як в повсякденній комунікації дітей, так і створенні правил класу тощо.

У процесі проведення експериментального дослідження протягом 2017-2018 навчального року в експериментальних класах були практично втілені методичні інструменти та зроблено узагальнення експериментальних даних. Також відбувалося опрацювання студентами педагогічної і навчально-методичної літератури з вказаного методичного доробку DOCCU. Посібники вміщують плани уроків для всіх рівнів навчання, метою яких $є$ сприяння активному громадянству, заснованому на активних і проблемно-спрямованих фрормах навчання в демократичних шкільних спільнотах. Авторами і редакторами остаточної версії $є$ представники багатьох європейських країн, а посібники безпосередньо були апробовані та перевірені великою кількістю людей різного походження і поглядів.

3 метою визначення ефективності експериментального дослідження у підвищенні ефективності процесу правового виховання учнів студенти-практиканти пропонували учням серію завдань правового змісту, аналізували відбір і використання матеріалів у процесі знайомства з правами людини, з'ясовували способи керівництва навчальним процесом і вибір форм навчання. Основними фрормами навчання правам були: навчання через викладання матеріалу, кероване дослідницьке навчання (обговорення у класі), відкрите навчання, індивідуальне навчання, проектне навчання. Також у процесі експериментальної роботи нас цікавило питання правової обізнаності молодших школярів.

У залежності від мети та обставин використовуватися роз'яснення; розповіді, колективні та індивідуальні бесіди; аналіз життєвих ситуації, обговорення з учнями літературних, літературно-публіцистичних творів, статей і повідомлень з відповідною правовою оцінкою того, що трапилось; читання художніх творів; вікторини; конкурси; написання творів на правову тематику; створення спеціальних педагогічних ситуацій, виборчі екскурсії; включення дітей у процес вибору органів самоврядування; ділові ігри (правові тренінги) [1].

Успішне проведення правового тренінгу передбачало виконання ряду вимог:

- своєчасність, превентивний характер змісту, орієнтованого на майбутні проблеми і на потреби учнів;

- відбір ситуацій та розробку формулювань, які здатні стимулювати інтерес учасників, різноманітність фрорм, методів, способів роботи;

- толерантність та повагу до дітей-учасників, не допущення приниження їх честі і гідності, самооцінки і самоповаги;

-збереження конфіденційності у разі повідомлення дітьми інтимної інфрормації;

- забезпечення особистої активності учасників;

- включення учасників як у взаємодопомогу, так і в самостійне вирішення своїх проблем;

- диференційований підхід до учасників, врахування їх наявного досвіду, установок, індивідуальних особливостей, труднощів;

- використання технічних засобів слайдів, відеофільмів тощо.

Використання методу моделювання виховних правових ситуацій допомагало молодшому школяреві долати обмеженість свого власного кругозору, формувало різні елементи соціального досвіду [5] .

Таким чином, учень приймає участь у: відборі, плануванні, постановці питань, відкритті, дослідженні, формулюванні, проектуванні, міркуванні, перевірці, управлінні. В експериментальних класах були впроваджені розробки уроків з таких тем : «Ідентичність: Я у своїй громаді», «Різноманіття та плюралізм», «Рівноправність: Меншини та більшість», «Конфлікт: Правила дозволяють вирішувати конфлікти», «Правила та закон: Основижиття разом», «Відповідальність: Я - за екологію... моя школа також», «Права та свободи: Для тебе? Для інших?».

Відповідно до цього наприкінці експериментального дослідження проводилися контрольні заміри рівня сформованості правових уявлень та правомірної поведінки учнів з експериментального і контрольного (який працював за традиційною методикою правового виховання) класів у кожній з базових шкіл.

У процесі аналізу відповідей учнів контрольного і експериментального класів на поставлені в анкеті запитання виявилося, що навіть на ті з них, які вимагають загальновідомих знань, не всі учні правильно відповіли. Проаналізувавши результати тренінгу «Права та обов'язки» виявилося, що деякі учні не розуміють різниці між цими двома поняттями. Такі поняття, як «Старанно вчитися» та «Навчатися» деякі учні вважають рівноцінними, хоча під 
час уроків з дисципліни «Я у світі» та тематичних класних годинах ці поняття не рідко розмежовувалися, вчитель детально пояснював суть цих понять. Варто звернути увагу, що дотримання правил руху (83\%), дотримання правил поведінки (80\%) та твердження щодо охорони природи (78\%) майже всі діти визначили обов'язком людини, а твердження про те, що гратися, відпочивати та розважатися (83\%) позначили правом людини, а не обов'язком дещо здивувало, оскільки припускалося, що учні школи І ступеню вважають гру своїм обов'язком .

Констатувальний етап дослідження дозволив визначити у процесі (анкетуваня дітей, їхніх батьків; бесід 3 учнями та вчителями; тестування з правової обізнаності) перевагу початкового (44\%) та середнього (56\%) рівнів сформованості правової культури молодших школярів, учнів із високим рівнем не визначено. Такі результати дали підставу для цілеспрямованого формування правових знань та правової культури в цілому.

На заключному етапі експерименту нами отримано дані щодо покращення сформованості навичок в експериментальних класах (ЕК) в порівнянні з контрольними (КК): початковий рівень виявлено у 22,8\% учнів ЕК, 40\% - КК; середній рівень правових знань продемонстрували 68,4\% ЕК та 60\% КК; високого рівня досягли $7,6 \%$ ЕК, але цей рівень знань був відсутнім в учнів КК. Отже, динаміка зростання середнього та високого рівнів сфрормованості правових знань, зокрема, та правової культури, в цілому, в експериментальних класах $є$ наявною. У процесі дослідницької роботи в експериментальних класах змінилися на кращі всі показники рівня правових уявлень на навичок демократичної поведінки молодших школярів. У контрольних ці показники змінилися певною мірою, але ці зміни значно менші.

\section{ВИСНОВКИ ТА ПЕРСПЕКТИВИ ПОДАЛЬШИХ ДОСЛІДЖЕНЬ}

Аналіз теоретичного доробку принципів, педагогічних умов та практичного впровадження матеріалів 3 правового виховання учнів на демократичних засадах, показав, що їх реалізація сприяє ефективному засвоєнню системи доступних для цієї категорії учнів правових понять, фоормуванню відповідних уявлень, а також позитивного досвіду правомірної поведінки і діяльності. Модель «конструювання» громадянських якостей включає і заохочує самовизначення, особисту відповідальність, орієнтацію на контекст знань. Таке навчання передбачає що, учні мають брати участь у прийнятті рішень, навчальне середовище заохочує учнів діяти (мобільне обладнання класної кімнати та навчального простору (широка різноманітність навчальних матеріалів, місця для проведення експериментів, малювання тощо), учням пропонується різноманітність тем і матеріалів на вибір.

\section{СПИСОК ВИКОРИСТАНИХ ДЖЕРЕЛ}

[1] Беремо участь у демократії: плани уроків з Одг/ОПЛ для старших класів середньої школи Р. Голлоб, П. Крапф, В. Вайдінгер. Пер. з англ. та адапт. Л. І. Паращенко, Ю. О. Молчанової; заг. ред. укр. версії: Н. Г. Протасова. К. : Основа, 2016. Т. 4. 294 с.

[2] Демократичне врядування в школах: посібник Елізабет Бекман і Бернард Траффорд / пер. з англ. та адапт. Л. І. Паращенко; заг. ред. укр. версії Н. Г. Протасова. К: НАДУ, 2009. 100 с.

[3] Навчаємо демократії : Базові матеріали з освіти для демократичного громадянства та освіти з прав людини для вчителів Р. Голлоб, П. Крапф, О. Олафсдоттір, В. Вайдінгер; ред. Р. Голлоб, П. Крапф, В. Вайдінгер: Пер. 3 англ. та адапт. Л. І. Паращенко. 3 тє вид. К.: Основа, 2016. Т. 1. 164 с.

[4] Нова Концепція української школи [Електронний ресурс] Л. Гриневич, О. Елькін,С. Калашнікова, І. Коберник, та ін.;за заг. ред.М. Грищенко. Режим доступу:http://www.oblosvita.mk.ua/attachments/article.

[5] Хартлей М. і Хадлестон Т. (2009), Партнерство шкіл, суспільства, університетів для підтримки стійкої демократії: Освіта для демократичного громадянства в Європі і Сполучених Штатах. Пакет ОДГ/ОПЛ, Том 5, Рада Європи, Страсбург, С. 8 (www.coe.int/edc).

\section{REFERENCES (TRANSLATED AND TRANSLITERATED)}

[1] Beremo uchastj u demokratiji: plany urokiv z ODGh/OPL dlja starshykh klasiv serednjoji shkoly R. Ghollob, P. Krapf, V. Vajdingher. Per. z anghl. ta adapt. L. I. Parashhenko, Ju. O. Molchanovoji; zagh. red. ukr. versiji: N. Gh. Protasova. K. : Osnova, 2016. T. 4. 294 s. (Participate in democracy: plans of lessons from education is for democracyforthe higher forms of high school. R. Ghollob, P. Krapf, V. Vajdingher. K. : Osnova, 2016. T. 4. 294 s.) (in Ukrainian)

[2] Demokratychne vrjaduvannja v shkolakh: posibnyk. Elizabet Bekman i Bernard Trafford / per. z anghl. ta adapt. L. I. Parashhenko; zagh. red. ukr. versiji N. Gh. Protasova. K: NADU, 2009. $100 \mathrm{~s}$. (Navchatysja i zhyty v demokratiji). (Democratic management in schools: Manual. Of Elisabeth Bekman and Bernard Trafford / trudged.from an england adapt. L. I. Parashhenko K: NADU, 2009. 100 s) (in Ukrainian)

[3] Navchajemo demokratij: Bazovi materialy z osvity dlja demokratychnogho ghromadjanstva ta osvity z prav ljudyny dlja vchyteliv / R. Ghollob, P. Krapf, O. Olafsdottir, V. Vajdingher; red. R. Ghollob, P. Krapf, V. Vajdingher: Per. z anghl. ta adapt. L. I. Parashhenko. 3 tje vyd. K.: Osnova, 2016. T. 1. 164 s. (Teach democracies :Base materials from education for democratic citizenship and education on human rights forteachers. R. Ghollob, P. Krapf, O. Olafsdottir, V. Vajdingher; red. R. Ghollob, P. Krapf, V. Vajdingher. K.: Osnova, 2016. T. 1. 164 s.) (in Ukrainian)

[4] Nova Koncepcija ukrajinsjkoji shkoly [Elektronnyj resurs] L. Ghrynevych, O. Eljkin,S. Kalashnikova, I. Kobernyk, ta in.; za zagh. red. M. Ghryshhenko. Rezhym dostupu:http://www.oblosvita.mk.ua/attachments/article. (New Conception of Ukrainian school [Electronic resource] L. Ghrynevych, O. Eljkin,S. Kalashnikova, I. Kobernyk, ta in.;za zagh. red.M. Ghryshhenko)

[5] Khartlej M. i Khadleston T. (2009), Partnerstvo shkil, suspiljstva, universytetiv dlja pidtrymky stijkoji demokratiji: Osvita dlja demokratychnogho ghromadjanstva v Jevropi i Spoluchenykh Shtatakh. Paket ODGh/OPL, Tom 5, Rada Jevropy, Strasburgh, S. 8 (www.coe.int/edc). (Khartlej M. i Khadleston T Partnership of schools, society, universities for support of proof democracy: Education for democratic citizenship in Europe and UnitedStates. Package of ОДГ/ОПЛ, Тom 5, СЕ, Strasbourg, С. 8) (in Ukrainian) 